\title{
GAUGING THE CURIOSITY OF TELEVISION VIEWERS - A COMPARATIVE STUDY ON COMIC VERSUS SERIOUS APPEALS WHEN PROMOTING HIGHER OR LOWER THOUGHT PRODUCTS
}

\author{
Syed Karamatullah Hussainy1 \\ PhD. Business Administration Student at Preston University, Karachi \\ Dean, Faculty of Management Sciences \\ Khadim Ali Shah Bukhari Institute of Technology (KASBIT)
}

Dr. Rukhsar Ahmed 2

Professor\& Dean, Post Doctorate in Management \& Law, HEC Approved Supervisor, HEC Approved Resource Person, PhD from University of Karachi

\begin{abstract}
Purpose: - The article attempts to explore the impact of advertising on gaining attention of television audience.

Methodology:-Simple random sampling technique was used for drawing multiple groups having twenty-five respondents, and they were exposed to multiple ads having comic and serious contents. The data was collected through questionnaire. Logistic regression method is applied through using t-test and chi-square for analysis.

Findings:-The study has identified many interesting dimensions including the diversity of advertising themes, gender and age differences. Comic and serious appeals are studied to identify their impact on television audience when used for higher thought and lower thought products.

Practical Implications:-The research has revealed many interesting facts that would help the advertisers develop a better theme for their television audience when attempting to gain the attention for promoting their higher thought or lower thought products. The research has given an opportunity to the researchers exploring the reaction of television audience in a simulated environment and has provided the researcher ample evidence to recommend advertisers, the various themes for different categories of products. It also would open new windows of research for researchers interested in conducting research on communicating through use of television ads with audience.
\end{abstract} \footnotetext{
and the management of the Institute of Business \& Technology (IBT)

${ }_{2}^{1}$ Syed Karamatullah Hussainy

:s.karamatullah@gmail.com

2 Dr. Rukhsar Ahmed :rukhsarahmed2000@yahoo.com

(C) IBT-JBS is published by the Institute of Business and Technology (IBT). Main Ibrahim Hydri Road, Korangi Creek, Karachi-75190, Pakistan.
}

* The material presented by the author does not necessarily portray the viewpoint of the editors 


\section{INTRODUCTION}

The article attempts to unearth the dimensions of television advertising. It shall enquire how comic and serious themes influence the intentions of viewers towards drawing the attention through use of advertising themes. The attention drawn through the use of advertising may in turn influence the selection of specific product or brand by the viewers. The marketers have explored and realized over time that advertising is a medium that holds immense power when it comes to drawing the attention of audience towards a specific product or brand. Various advertising themes may draw different levels of attention in order to make the viewers understand the differences that a brand may have over its competing brand to gain competitive advantage in the market.

The article shall cover some key impacts that advertising may have on the audience when the objective is to draw the attention of its viewers in order to influence the intention of buyers. The areas that would be explored include:

How much influence does advertising appeals has when drawing the attention of the audience is required towards a specific brand?

How many categories of advertising appeals can advertisers use in drawing the attention of audience and what influence they have on the viewers?

How much influence comic appeals are able to generate towards the viewers in drawing their attention?

Do comic appeals impact differently on different categories of product at the attention stage?

Advertisers spend large sum of dollars on promotional campaigns in order to draw the attention of audience towards a specific brand or product. The challenge faced byadvertisers is to maximize the impact of the dollars spent on advertising by minimizing the wastage of resources for achieving the objective. According to a research done by (Weinberger and Spotts, 1992)estimated that seventy six percent ads did not use comic themes in North America whereasthe remaining ads did show an involvement of comic themes. Other researchers who explored the same dimensions did also report equal or greater involvement of comic themes in television commercials. The researchers include (Markiewicz, 1974), (Kelly and Solomon, 1975) and in radio (Weinberger and Campbell, 1991).

Use of comic themes is substantially higher which proves that it is a technique preferred by advertisers and may be an adequately efficient source for gaining attention of audience. At the same time, it still needs to be explored whether the effectiveness 
Gauging the Curiosity of Television Viewers - a Comparative Study on Comic Versus Serious Appeals When Promoting Higher or Lower Thought Products

of comic appeals is equally substantial as compare to other advertising themes or not.(Sternthal and Craig, 1973) considered use of comic advertising themes as a sensitive dimension that may not be considered as appropriate by many advertisers. A research involving top officials of advertising world was conducted by (Madden and Weinberger, 1984). Only six percent top executives of leading US Ad Agencies did not agree that comic themes is an effective method whereas the rest large majority did agree that comic themes have a significant influence on the viewers. These top officials were of the opinion that comic advertising themes did show a significant influence on the viewers when it comes to memorizing the brand, comprehension of small product attributes, preservation of brand in memory, frame of mind and brand transferability whereas all researchers do not reveal the same impact. Some studies have rejected the impact of comic appeals on audience at attention stage. A research conducted by (Runyon, 1979) established that comic appeals may not be appropriate when it is used for promoting issues that involve serious consequences like death, disease etc. As a whole, previous studies do not agree that use of comic appeals have any significant difference in drawing attention when compared by other commercial themes. The findings may be influenced due to some other variables that are ignored in the previous studies. A variable ignored can damage the effectiveness of comic themes that is not considered as significant by advertisers. Therefore in order to gain a higher influence on attention when comic appeals are used, such variables must be given their due importance and the variables may include viewers, kind of comic appeals, and picturization of brand elements. It means that comic themes may show a higher degree of influence on attention if they are properly used especially in televised ads and may not be that influence in print or still advertisement mediums. It is also important that the product category selected for comic themes should also be appropriate for the comic themes.

\section{PROBLEM AND ITS BACKGROUND}

\subsection{Humor in Advertising}

The impact of comic themes has been researched by large number of scholars and they have found many interesting dimensions that influence viewers' attention. (Weinberger, Gulas, \& Charles, 1992) in a study represented the research findings in the form of a diagram and identified the various aspects that may be established in comic ads. Further the study identified that a large number of dimensions may interdependently influence each other and this interdependency may open new windows of investigations that researchers may inquire into and find influences that may impact attention of viewers.

The diagrammatic representation of (Weinberger, Gulas, \& Charles, 1992) established non complex, easy understandable, interdependent influences based on the study. If explained in easier term, it can be said that development of humorous appeals may show significant impacts under specific scenarios. Designing a theme for an advertising campaign that would influence an individual's mind whose behavior needs to be molded in favor of a specific brand is a complex activity. Comic creative themes not only influence a specific category of product; it may also establish a significant influence on a wide variety of products that may range from 
highly tangible to highly intangible group of products. (Berger, 1981) stated that use of comic appeals comic creative ideas for promoting product may influence high variety of product range and show a significant influence on changing attitude of individuals. 0.4 trillion US dollars annually is spent by companies to gain the favor of audience in the world when promoting wide range of products that may include highly tangible to highly intangible categories of products. This in reality means that huge amounts are included in the pricing of products used for promoting products. It was also established (Elliott and Speck, 1998) that expenses done on developing creative advertising themes have reached to substantial stage. The phenomenon was further explained by (Davis, 2000) that audience may be exposed to approximately five thousand nine hundred and ninety five commercials in a single calendar whereas the audience may also received appeals of more than two thousand five hundred new offers in twelve months. Conventional schools of creative themes development established difference on numerous attributes. Themes developed by conventional schools are now used by contemporary advertisers when promoting products of various categories, it may be noted at this juncture that such themes are innovated to make them in line with the modern environment thus creating a new innovated theme in the contemporary advertising world. Advertisers are tilting towards developing such creative ideas in all range of advertising themes of the modern environment. Creative themes provide advertisers a platform where they can communicate with the audience and convince them about the benefits that the audience may draw from a product use in their communiqué. Such paid non personal forms of communications may be used together with other forms of communications. The concept was further explained by (Clow and Baack, 2002) that communicating with audience would also help the audience establish relationship with the advertisers that are the manufacturers of a product. It is a known fact now that manufacturers or producers have been using different creative ideas for the purpose of promotion right from the beginning of human's known history. Initially figurative graphic themes were used by different civilizations to communicate with different communities that occupied the planet in those eras.

Considering the history of creative themes for promoting various products in the modern era, advertising has become an integral part that cannot be ignored by producers of various products for gaining favor from their target market in the cluttered and complex societies.

\subsection{Rationalization}

Based on the literature reviewed and the findings of various studies, it can be said that advertising plays a pivotal role when companies try to promote their brands in a given segment or target market. Out of the two major promotional options, advertising perhaps is the most economical, feasible and reachable option when it comes to promoting products in the mass markets. Considering the importance of advertising, it is equally important to research, review and recommend the best possible themes that may be developed by advertisers for advertising a specific brand.

The study shall explore the impact of comic and serious appeals on gaining attention among audience of various categories of product specifically when comic and serious appeals are used for gaining attention of higher thought products (HTP) and lower thought products (LTP). HTP are defined as products that require extensive time, effort and amount of purchasers whereas LTP are products that require limited time, effort and amount of purchasers. The study shall also explore whether use of serious or comic 
Gauging the Curiosity of Television Viewers - a Comparative Study on Comic Versus Serious Appeals When Promoting Higher or Lower Thought Products

appeals significantly impact differently when used for HTP and LTP.

The article has developed, researched and analyzed the following hypotheses:

Ho: Comic and serious appeals do not influence equally on attention of audience

H1: Comic and serious appeals influence equally on attention of audience

Ho: Comic appeals used for higher thought products do not influence attention of audience.

H1: Comic appeals used for higher thought products influence attention of audience.

Ho: Comic appeals used for lower thought products do not influence attention of audience.

H1: Comic appeals used for lower thought products influence attention of audience.

Ho: Serious appeals used for higher thought products do not influence attention of audience.

H1: Serious appeals used for higher thought products influence attention of audience.

Ho: Serious appeals used for lower thought products do not influence attention of audience.

H1: Serious appeals used for lower thought products influence attention of audience.

\section{RESEARCH METHODOLOGY}

The research model explored the relationship between serious and comic appeals used for higher and lower thought products at the stage of attention. In order to investigate this relationship, the research needed to explore the level of attention when different types of appeals used for different categories of products were exposed to the audience. The method used for collecting the data was self expressive that is the audience who were exposed to the advertisements was asked with a help of a questionnaire that is which ad/ads received their highest attention. For this purpose, a simulated environment was created in which four groups of different age brackets and both genders were drawn. After exposing the ads to the groups, a questionnaire was circulated among the audience in which each respondent was supposed to provide information about two ads which drew their maximum attention. Based upon the information received, the frequency of preference was calculated among the eight ads exposed to each group. The eight ads included four serious and four comic advertisements. It was further classified into two serious and comic advertisements each for higher thought products and lower thought products. The information provided the researcher an insight to which ad was able to 
draw the maximum attention.

Data collected was then analyzed and interpreted with the help of SPSS and the statistical tools used for Chi Square Test of Independence and Logistics Regression Test. The data analysis revealed many interesting and intriguing dimensions on the research topic that are presented in this article.

\section{DATA ANALYSIS AND INTERPRETATION}

\subsection{Analysis of Attention}

The analysis presented in table 1,2, and 3 and pictorially depicted in figure 1shows that one hundred and twenty respondents who were exposed to eight ads, two each for comic and serious appeals used for higher and lower thought products. The results drawn from the respondents have revealed that the first most preferred ad which drew the maximum attention of the audience was McDonald Comic Advertisement, it was chosen by fifty five respondents whereas thirty respondents selected Dairy Milk Comic Advertisement. Both of these ads are comic and promoted lower thought products. Another fourteen respondents selected First for Women Insurance Advertisement which again a comic ad that is promoting higher thought product. In total, ninety nine respondents selected comic appeals when it comes to drawing their attention.

Further when the data is analyzed using Chi Square Test, the results show that the tabulated value at ninety five percent confidence level is less than the calculated value which is 162.8 whereas significance value is 0.000 , therefore the research is unable to negate the null hypothesis that is "Serious and Comic Appeals do not have an equal impact on the viewers' attention".

The research findings reveal that comic appeals have shown higher impact on the viewers as compare to serious appeals. The impact is even greater when comic appeals are used for lower thought products.

Based on table 4, the study further analyzes the factors that were responsible for impacting the attention of audience. 81 respondents out of 120 preferred action and dialogues as the elements for getting their highest attention. The tabulated value at ninety five percent confidence level has fallen below the calculated value that is 243.80 whereas the level of significance is 0.000 . This means that actions and dialogues are the two most important elements of getting audience attention. Therefore the study fails to reject the null hypothesis that is "Pasteurization, Action and Dialogues do not influence equally on audience at the level of attention"

Table 5, 6, 7 and figure 2 similarly show when the audience was required to identify the second most influencing ad that was able to draw their attention, forty three respondents selected McDonalds and forty two respondents selected dairy milk ad. 
Both were comic and related to lower thought product advertisements. Whereas seven respondents selected Volkswagen and six respondents selected first for women advertisements which were comic and related to higher thought products. In total ninety eight respondents preferred comic ads used for promoting products. This means that comic advertisements are also the second most preferred ads out of one hundred and twenty respondents.

The same is established with the help of Chi Square Analysis as at ninety five percent confidence level, the tabulated value is less than the calculated value which is 138.667 and the level of significance is 0.000 , hence it proves that the study is unable to reject the null hypothesis that is "Comic and serious appeals do not influence equally on attention of audience".

Same findings were established in the second most preferred ad when analysis was done about the reasons behind the preference of an ad at the level of attention. Sixty four respondents out of one hundred and twenty selected actions and dialogues as the most influencing factors.

The analysis also confirms the findings as ninety five percent confidence level, the tabulated value is less than the calculated value 98.583 and the level of significance is 0.000 , therefore the research is unable to reject the null hypothesis that is "Picturization, action and dialogues do not have equal influence on attention of audience"

\subsection{Research Model Attention Analysis}

Logistic Regression Analysis is done in order to check the impact of comic and serious appeals on higher thought and lower thought products when they are used for gaining attention of the audience. The null hypotheses that are tested in order to determine the impact of advertising appeals on various categories of products at attention level are:

Ho: Comic appeals used for higher thought products do not influence attention of audience.

H1: Comic appeals used for higher thought products influence attention of audience.

Ho: Comic appeals used for lower thought products do not influence attention of audience.

H1: Comic appeals used for lower thought products influence attention of audience.

Ho: Serious appeals used for higher thought products do not influence attention of audience.

H1: Serious appeals used for higher thought products influence attention of audience. 
Ho: Serious appeals used for lower thought products do not influence attention of audience.

H1: Serious appeals used for lower thought products influence attention of audience.

The data gathered and analyzed have given the following findings:

Logistic regression table 8 and 9 analyze and show that the investigation done keeping comic appeals as independent variable when used for higher thought products on attention of audience as dependent variable has revealed in a reduction of the Chi Square value calculated as 11.604 in the $-2 \log$ likelihood which is greater than the tabulated value and the $\mathrm{P}$ significance value is 0.001 which is less than 0.05 . Therefore, the study is able to reject the null hypothesis that is "Comic appeals used for higher thought products do not impact the attention of audience" and proves that comic appeals used for higher thought products impact the attention of audience.

Table 10 depicts that the likelihood of attention for the said variable is 0.930 which is less than onetherefore respondents have demonstrated higher level of attention when the comic appeal was not used in higher thought products. Following equation has been derived from the table 10:

\section{Attention $(\mathrm{y})=-0.942-0.930 \mathrm{X} 1$}

$\mathrm{X} 1=$ Comic Appeal, HTP

The logistic regression analysis further indicates that the comic appeals used for higher thought products have an impact on attention of audience. The data inputted and the results show that the $\mathrm{B}$ exponential value is 0.395 which is less than 1 . That means, if comic appeal is used for higher thought products, the attention of audience would decrease. This reveals that when higher thought products are to be promoted, comic appeals may not be a very feasible option. As the equation derived from the above table also proves this finding.

Table 11 and 12 explain that the investigation done keeping comic appeals as independent variable when used for lower thought products on attention of audience as dependent variable has revealed in a reduction of the Chi Square value calculated as 178.810 in the $-2 \log$ likelihood which is greater than the tabulated value and the level of significance is 0.000 which is less than 0.05 . Therefore the study rejects the null hypothesis that is "Comic appeals used for lower thought products do not influence attention of audience", which mean that comic appeals used for lower thought products significantly impact the attention of the audience.

In table 13 , the logistic regression analysis further explains that the exponential $\mathrm{B}$ value of comic appeals used for lower thought products is calculated as 26.84 which is greater than 1 . This means that when comic appeals are used for promoting lower thought products, the attention of audience is higher. This is also proved by the following equation: 
Attention $(\mathrm{y})=-2.362+3.290 \mathrm{X} 1$

$\mathrm{X} 1$ = Comic Appeal, LTP

Table 14 and 15 elaborate that the investigation done keeping serious appeals as independent variable when used for higher thought products on attention of audience as dependent variable has revealed in a reduction of the Chi Square value calculated as 36.62 in the $-2 \log$ likelihood column which is greater than the tabulated value and the level of significance is 0.000 which is less than 0.05 therefore the study rejects the null hypothesis that is "Serious appeals used for HTP do not have any influence on attention of audience". This means that serious appeals have a significant impact on attention of audience when higher thought products are to be promoted.

Table 16 shows that the model further explores using logistic regression method to determine the impact of serious appeals for promoting higher thought products and the analysis revealed that the $\mathrm{B}$ exponential value is 0.141 which is less than 1 . This means that although serious appeals influence attention but in reality it may decrease the attention among audience. This is also expressed with the help of following equation:

$$
\text { Attention }(\mathrm{y})=-0.821-1.960
$$

$\mathrm{X} 1$ = Serious, HTP

Table 17 and 18 revealed that the investigation done keeping serious appeals as independent variable when used for lower thought products on attention of audience as dependent variable has revealed in a reduction of the Chi Square value calculated as 32.863 in the -2 Log likelihood column which is less than the tabulated value and the level of significance is 0.000 which is less than 0.05 therefore the research rejects the null hypothesis "Serious appeals used for lower thought products do not influence attention of audience." It means that serious appeals used for lower thought products have a significant impact on audience at the level of attention.

Table 19 identifies that the model further investigates and the findings of logistic regression analysis have revealed that the exponential B value is 0.164 which is less than 1. It means that serious appeals used for lower thought products may not be very feasible for promoting lower thought products and this is also proved by the following equation

$$
\begin{aligned}
& \text { Attention }(\mathrm{y})=-0.834-1.805 \mathrm{X} 1 \\
& \mathrm{X} 1=\text { Serious, LTP }
\end{aligned}
$$

\section{CONCLUSION AND RECOMMENDATIONS}

Based on the analysis and interpretations, the research fails to reject the following null hypothesis: 
Ho: Comic and serious appeals do not influence equally on attention of audience Following Null Hypotheses are rejected:

Ho: Comic appeals used for higher thought products do not influence attention of audience.

Ho: Comic appeals used for lower thought products do not influence attention of audience.

Ho: Serious appeals used for higher thought products do not influence attention of audience.

Ho: Serious appeals used for lower thought products do not influence attention of audience.

Following Alternate Hypothesis is rejected:

H1: Comic and serious appeals influence equally on attention of audience Following Alternate Hypotheses are accepted:

H1: Comic appeals used for higher thought products influence attention of audience.

H1: Comic appeals used for lower thought products influence attention of audience.

H1: Serious appeals used for higher thought products influence attention of audience.

H1: Serious appeals used for lower thought products influence attention of audience.

Based on the analysis, the research concludes that comic and serious appeals influence differently when they are used for promoting higher or lower thought products. Further investigations also prove that comic appeals when used for lower though products have the highest impact on attention but when they are used for promoting higher though products, they influence audience although the influence is negative in fact it significantly decreases the attention level of audience. Similarly when serious appeals are used for promoting lower or higher thought products, their influence are significant but they cannot match the level of attention when comic appeals are used for promoting lower though products whereas serious appeals may show a higher level of attention as compare to comic appeals when they are used for higher thought products.

This means that advertisers must give serious consideration for using comic appeals when lower thought products are to be promoted as the influence on audience is so immensethat it cannot be neglected whereas serious appeals may be a better option when advertisers are trying to promote higher thought products. 


\section{REFERENCES}

Clow, K. \&Baack, D. (2002) 'Integrated advertising, promotion and marketing communications', Journal of Marketing Communications, 9(3), pp. 193-194.

Weinberger, M. G \&Spotts, H. E. (1992) 'Difference in British and American television and magazine advertising: myth or reality',in G. J. Bamossy\& W. F Raaij, (Eds.), Proceedings of the Association for Consumer Research: European Summer Conference.

Markiewicz, D. (1974) 'Effects of humor on persuasion',Sociometry, 37(3), pp. 407422.

Kelly, J. \& Solomon,P.(1975) 'Humor in television advertising', Journal of Advertising,4(3), pp. 31-35.

Weinberger, M. \& Campbell (1991) 'The Impact of Humor in Advertising', Journal of Advertising, pp. 35-35.

Sternthal,B. \& Craig, S. (1973) 'Humor in advertising',Journal of Marketing,37(4), pp. 12-18.

Runyon, K.E. (1979) 'Advertising and the Practice of Marketing. Columbus: OH, Charles E. Merrill.

Madden, T. \& Weinberger, M. (1984) 'Humor in advertising: A practitioner view,' Journal of Advertising Research, 24(4), pp. 23-29.

Elliott, M. \& Speck, P. (1998) 'Consumer perceptions of advertising clutter and its impact across various media',Journal of Advertising Research, 38(1), pp. 29-41.

Weinberger, Marc, G; Gulas, Charles S. (1992) 'The impact of humor in advertising: A review', Journal of Advertising, 21(4), pp.35-35.

Berger, D. (1981) 'A retrospective: FCB recall study’, Advertising Age, pp. 36-38. 


\section{APPENDIX}

Chi Square test for attention (Advertisement One)

Table: 1 Descriptive statistics

\begin{tabular}{|l|l|l|l|l|l|}
\hline & N & Mean & Std. Deviation & Minimum & Maximum \\
\hline Please identify the advertisement & 120 & 4.84 & 2.376 & 1 & 8 \\
\hline
\end{tabular}

Table 2: Please identify the first preferred advertisement that drew your maximum attention.

\begin{tabular}{|l|l|l|l|}
\hline & Observed N & Expected N & Residual \\
\hline First for Women Insurance(Comic) & 14 & 15.0 & -1.0 \\
\hline Capital One(Serious) & 8 & 15.0 & -7.0 \\
\hline Cadbury Dairy Milk(Comic) & 30 & 15.0 & 15.0 \\
\hline Aqua Fresh 3 (Serious) & 2 & 15.0 & -13.0 \\
\hline Volkswagen(Comic) & 6 & 15.0 & -9.0 \\
\hline Colorado State University (Serious) & 1 & 15.0 & -14.0 \\
\hline McDonalds (Comic) & 55 & 15.0 & 40.0 \\
\hline Cadbury Dairy Milk Bubbly (Serious) & 4 & 15.0 & -11.0 \\
\hline Total & 120 & & \\
\hline
\end{tabular}

Table 3: Test statistics

\begin{tabular}{|l|l|}
\hline & $\begin{array}{l}\text { Please identify the first preferred } \\
\text { advertisement that drew your maximum } \\
\text { attention }\end{array}$ \\
\hline Chi-Square & $162.800 \mathrm{a}$ \\
\hline Df & 7 \\
\hline Asymp. Sig. & .000 \\
\hline
\end{tabular}

0 cells $(0.0 \%)$ have expected frequencies less than 5 . The minimum expected cell frequency is 15.0

Figure : 1 Ad one, attention level

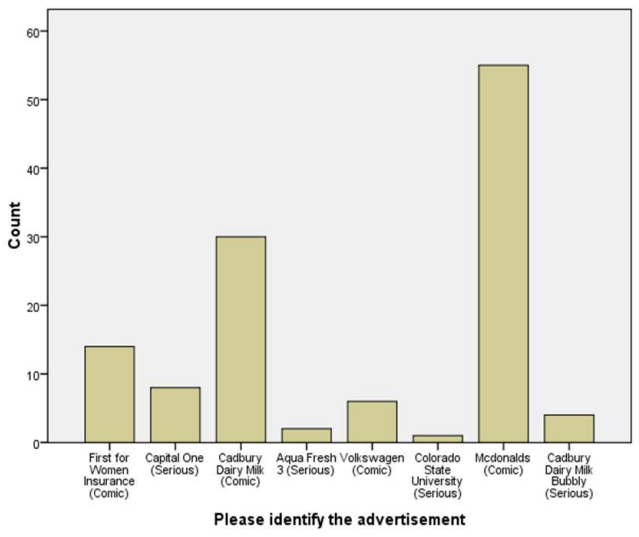


Table 4: Test statistics

\begin{tabular}{|l|l|}
\hline & Why the advertisement took your attention? \\
\hline Chi-Square & $243.800 \mathrm{a}$ \\
\hline Df & 5 \\
\hline Asymp. Sig. & .000 \\
\hline
\end{tabular}

a. 0 cells $(0.0 \%)$ have expected frequencies less than 5 . The minimum expected cell frequency is 20.0 .

Chi Square test for attention (Advertisement Two)

Table 5: Descriptive statistics

\begin{tabular}{|l|l|l|l|l|l|}
\hline & $\mathbf{N}$ & Mean & Std. Deviation & Minimum & Maximum \\
\hline $\begin{array}{l}\text { Please identify the first } \\
\text { preferred advertisement that } \\
\text { drew your maximum } \\
\text { attention. }\end{array}$ & 120 & 5.05 & 2.188 & 1 & 8 \\
\hline
\end{tabular}

Table 6: Please identify the second preferred advertisement that drew your maximum attention

\begin{tabular}{|l|l|l|l|}
\hline & Observed N & Expected N & Residual \\
\hline First for Women Insurance (Comic) & 6 & 15.0 & -9.0 \\
\hline Capital One (Serious) & 2 & 15.0 & -13.0 \\
\hline Cadbury Dairy Milk (Comic) & 42 & 15.0 & 27.0 \\
\hline Aqua Fresh 3 (Serious) & 5 & 15.0 & -10.0 \\
\hline Volkswagen (Comic) & 7 & 15.0 & -8.0 \\
\hline Colorado State University (Serious) & 3 & 15.0 & -12.0 \\
\hline McDonalds (Comic) & 43 & 15.0 & 28.0 \\
\hline Cadbury Dairy Milk Bubbly (Serious) & 12 & 15.0 & -3.0 \\
\hline Total & 120 & & \\
\hline
\end{tabular}


Figure : Ad Two, attention level

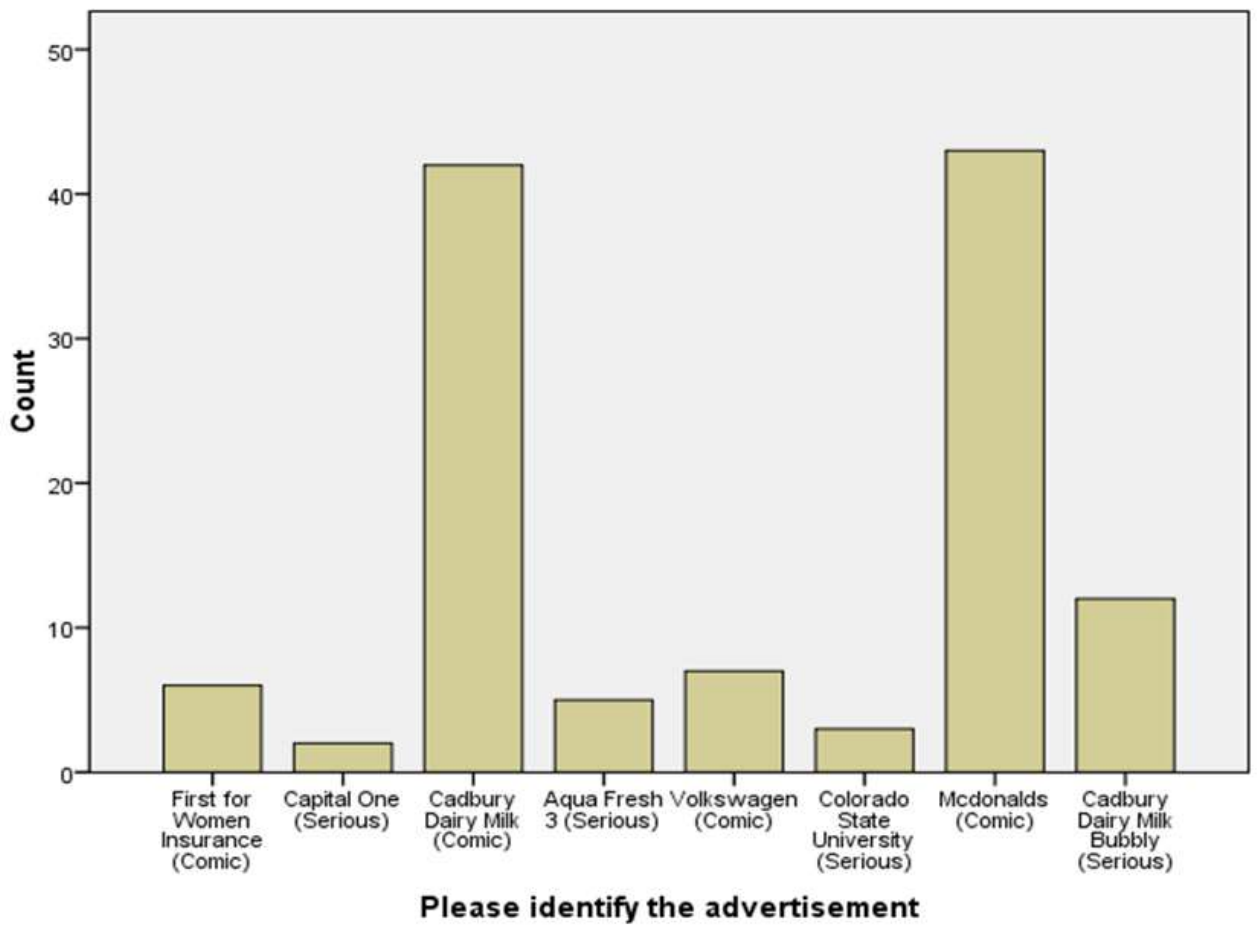

Table 7: Test statistics

\begin{tabular}{|l|l|}
\hline & Please identify the advertisement \\
\hline Chi-Square & $138.667 \mathrm{a}$ \\
\hline Df & 7 \\
\hline Asymp. Sig. & .000 \\
\hline
\end{tabular}

Logistic Regression, Comic Higher Thought Products

Table 8: Omnibus tests of model coefficients

\begin{tabular}{|l|l|l|l|l|}
\hline & & Chi-square & df & Sig. \\
\hline Step 1 & Step & 11.604 & 1 & .001 \\
\hline & Block & 11.604 & 1 & .001 \\
\hline & Model & 11.604 & 1 & .001 \\
\hline
\end{tabular}


Table 9: Model Summary

\begin{tabular}{|l|l|l|l|}
\hline Step & -2 Log likelihood & Cox \& Snell R Square & Nagelkerke R Square \\
\hline 1 & $521.545^{\mathrm{a}}$ & .024 & .036 \\
\hline
\end{tabular}

a. Estimation terminated at iteration number 4 because parameter estimates changed by less than .001

Table 10: Variables in the equation

\begin{tabular}{|l|l|l|l|l|l|l|}
\hline & & B & S.E. & Wald & df & Sig. \\
\hline Step $1^{\mathrm{a}}$ & CHExp & -.930 & .293 & 10.073 & 1 & .002 \\
\hline & Constant & -.942 & .117 & 64.439 & 1 & .000 \\
\hline
\end{tabular}

a. Variable(s) entered on step 1: CHExp.

LogisticÊRegression, Comic Lower Thought Products

Table 11: Omnibus tests of model coefficients

\begin{tabular}{|l|l|l|l|l|}
\hline & & Chi-square & df & Sig. \\
\hline \multirow{3}{*}{ Step 1 } & Step & 178.810 & 1 & .000 \\
\cline { 2 - 5 } & Block & 178.810 & 1 & .000 \\
\cline { 2 - 5 } & Model & 178.810 & 1 & .000 \\
\hline
\end{tabular}

Table 12: Model summary

\begin{tabular}{|l|l|l|l|}
\hline Step & -2 Log likelihood & Cox \& Snell R Square & Nagelkerke R Square \\
\hline 1 & $354.339 a$ & .311 & .464 \\
\hline
\end{tabular}

a. Estimation terminated at iteration number 5 because parameter estimates changed by less than .001 .

Table 13: Variables in the equation

\begin{tabular}{|c|c|c|c|c|c|c|c|}
\hline & & B & S.E. & Wald & df & Sig. & $\operatorname{Exp}(\mathrm{B})$ \\
\hline \multirow[t]{2}{*}{ Step 1a } & CLExp & 3.290 & .276 & 141.798 & 1 & .000 & 26.844 \\
\hline & Constant & -2.362 & .188 & 158.067 & 1 & .000 & .094 \\
\hline \multicolumn{5}{|c|}{ a. Variable(s) entered on step 1: CLExp. } & & & \\
\hline
\end{tabular}

\section{Logistic Regression, Serious Higher Thought Products}

Table 14: Omnibus tests of model coefficients

\begin{tabular}{|l|l|l|l|l|}
\hline & & Chi-square & Df & Sig. \\
\hline Step 1 & Step & 36.625 & 1 & .000 \\
\cline { 2 - 5 } & Block & 36.625 & 1 & .000 \\
\cline { 2 - 5 } & Model & 36.625 & 1 & .000 \\
\hline
\end{tabular}


Table 15: Model summary

\begin{tabular}{|l|l|l|l|}
\hline Step & -2 Log likelihood & Cox \& Snell R Square & Nagelkerke R Square \\
\hline 1 & $496.524 \mathrm{a}$ & .073 & .110 \\
\hline
\end{tabular}

Table 16: Variables in the equation

\begin{tabular}{|c|c|c|c|c|c|c|c|}
\hline & & B & S.E. & Wald & df & Sig. & $\operatorname{Exp}(B)$ \\
\hline \multirow[t]{2}{*}{ Step 1a } & SHExp & -1.960 & .406 & 23.323 & 1 & .000 & .141 \\
\hline & Constant & -.821 & .114 & 51.487 & 1 & .000 & .440 \\
\hline
\end{tabular}

Variable(s) entered on step 1: SHExp.

LogisticÊRegression, Serious Lower Thought Products

Table 17: Omnibus tests of model coefficients

\begin{tabular}{|l|l|l|l|l|}
\hline & & Chi-square & Df & Sig. \\
\hline \multirow{3}{*}{ Step 1 } & Step & 32.863 & 1 & .000 \\
\cline { 2 - 5 } & Block & 32.863 & 1 & .000 \\
\cline { 2 - 5 } & Model & 32.863 & 1 & .000 \\
\hline
\end{tabular}

Table 18: Model summary

\begin{tabular}{|l|l|l|l|}
\hline Step & -2 Log likelihood & Cox \& Snell R Square & Nagelkerke R Square \\
\hline 1 & $500.287 \mathrm{a}$ & .066 & .099 \\
\hline
\end{tabular}

a. Estimation terminated at iteration number 5 because parameter estimates changed by less than .001 .

Table 19: Variables in the equation

\begin{tabular}{|l|l|l|l|l|l|l|l|}
\hline & & B & S.E. & Wald & Df & Sig. & Exp(B) \\
\hline \multirow{2}{*}{ Step 1a } & SLExp & -1.805 & .384 & 22.149 & 1 & .000 & .164 \\
\cline { 2 - 8 } & Constant & -.834 & .115 & 52.874 & 1 & .000 & .434 \\
\hline
\end{tabular}

a. Variable(s) entered on step 1: SLExp 